\title{
Elephantiasis nostras verrucosa associated with chronic constipation in a low-weight patient
}

\author{
Zayif bir hastada kronik konstipasyon ile ilișkili elefantiyazis nostras verrükoza
}

๑ Çağrı Turan, ๑ Ișıl Göğem İmren, ๑ Sonay Aydın*, ๑ Pınar Çelepli**, ๑ Hatice Meral Ekșioğlu

Ankara Health Practice and Research Center, Department of Skin and Venereal Diseases; *Department of Radiology; **Department of Pathology, Ankara, Turkey

\begin{abstract} compressed the iliac veins.

Öz kolon segmentlerinin iliak venleri sıkıştırdığı görülmektedir.

\section{Introduction}

Elephantiasis nostras verrucosa (ENV) is a rare, chronic, progressive, relapsing disease characterized by non-filarial lymphedema. ENV, seen mainly with bilateral leg involvement, is a disorder characterized by papules and verrucous lesions. Obesity and soft tissue infection are the preponderant risk factors of ENV ${ }^{1}$. Herein, we described a severe ENV case arising from chronic constipation despite low-weight, which is the first case in literature to our knowledge.
\end{abstract}

Elephantiasis nostras verrucosa (ENV) is a chronic, progressive disease closely associated with obesity. We report a weak 51-year-old male patient with a long history of constipation due to Hirschsprung's disease, a decrease in venous return due to prolonged abdominal distention during ileus attacks, and eventually a severe ENV clinic. Abdominal tomography of the patient shows that the expanded column segments

Keywords: Elephantiasis, stasis dermatitis, constipation, Hirschsprung disease, social withdrawal

Elefantiyazis nostras verrükoza (ENV), obezite ile yakından ilişkili kronik, ilerleyici bir hastalıktır. Burada, Hirschsprung hastalığı nedeniyle uzun zamandır kabızlığı olan hastada ileus atakları sırasında uzun süren abdominal distansiyon gelişmesi nedeniyle venöz dönüşte azalma ve nihayetinde ciddi düzeyde ENV kliniği gelişen 51 yaşında zayıf bir erkek hasta bildirilmiştir. Hastanın abdominal tomografisinde genişletilmiş

Anahtar Kelimeler: Elefantiyazis, staz dermatiti, kabızlık, Hirschsprung hastalığı, sosyal geri çekilme

\section{Case Report}

A 51-year-old male patient was admitted with profoundly malodorous, hyperkeratotic, purulent, painful lesions on the legs, especially marked on the left leg. Patient who did not care for personal hygiene had been brought to our hospital by his relatives after the patient's legs began to smell malodorous.

His complaints initiated at the age of 37 years with swelling and wounds on the left leg. Similar complaints of the right leg occurred over time. The patient had been treated with systemic and topical antibiotics hitherto when his complaints

Address for Correspondence/Yazıșma Adresi: Çağrı Turan MD, Ankara Health Practice and Research Center, Department of Skin and Venereal Diseases, Ankara, Turkey Phone: +90 3125953000 E-mail: cagrituranmd@gmail.com Received/Geliş Tarihi: 12.08.2018 Accepted/Kabul Tarihi: 09.10.2019 ORCID: orcid.org/0000-0002-6111-4314

(c) Copyright 2020 by Turkish Society of Dermatology and Venereology

Turkderm - Turkish Archives of Dermatology and Venereology published by Galenos Yayinevi. 
of pain, swelling, wound appeared. He had undergone Hirschsprung's disease. His medical history was negative for filariasis, familial Milroy's disease, surgery, radiation, neoplasia. He had never been abroad.

He wasn't obese with body mass index (BMI) at $16.6 \mathrm{~kg} / \mathrm{m}^{2}$. In the examination, there was diameter difference between the legs, nonpitting edema on the bilateral lower limbs covered with yellow-brown, thick hyperkeratosis and cobblestone-like appearance under the peeled crusts, especially substantial over the nearly whole extensor aspect of left leg while there were similar plaques with peripheral ecchymosis on the medial malleolus and middle of the leg on the right side (Figure 1). There was no reflection with the Wood's light examination carried out to exclude Pseudomonas pyoderma. The remainder of the examination was normal.

We conducted multiple punch biopsy, tuberculosis, fungal and bacterial cultures from the skin due to considering ENV, blastomycosislike pyoderma, tuberculosis verrucosa cutis, chromoblastomycosis, verrucous/squamous cell carcinoma in the differential diagnosis.

Intravenous antibiotic (ampisilin-sulbaktam) was administered empirically just after admission. In addition, potassium permanganate bath mitigated his pain and bad smell within one week and the patient's thick yellow-brown crusts intermittently underwent debridement (Figure 2).

A comprehensive blood examination did not show any abnormalities other than sedimentation (48 mm/hr normal range: $0-20 \mathrm{~mm} / \mathrm{hr}$ ) and C-reactive protein $(8.2 \mathrm{mg} / \mathrm{dL}$ normal range: $0-5 \mathrm{mg} / \mathrm{dL})$. Occult blood in the stool was negative as well. In the PPD test of the BCG-vaccinated patient, the area of induration was measured at a diameter of $10 \mathrm{~mm}$. Staphylococcus aureus, sensitive to aminopenicillins, was isolated from culture obtained purulent lesion areas. No fungus and tuberculosis bacillus were grown.

Examination of histopathologic sections revealed orthokeratosis, irregular acanthosis, focal parakeratosis, mild spongiosis in the epidermis as well as acute and chronic stasis findings such as extravascular erythrocytes and hemosiderin-laden macrophages, fibro-myxoid stroma

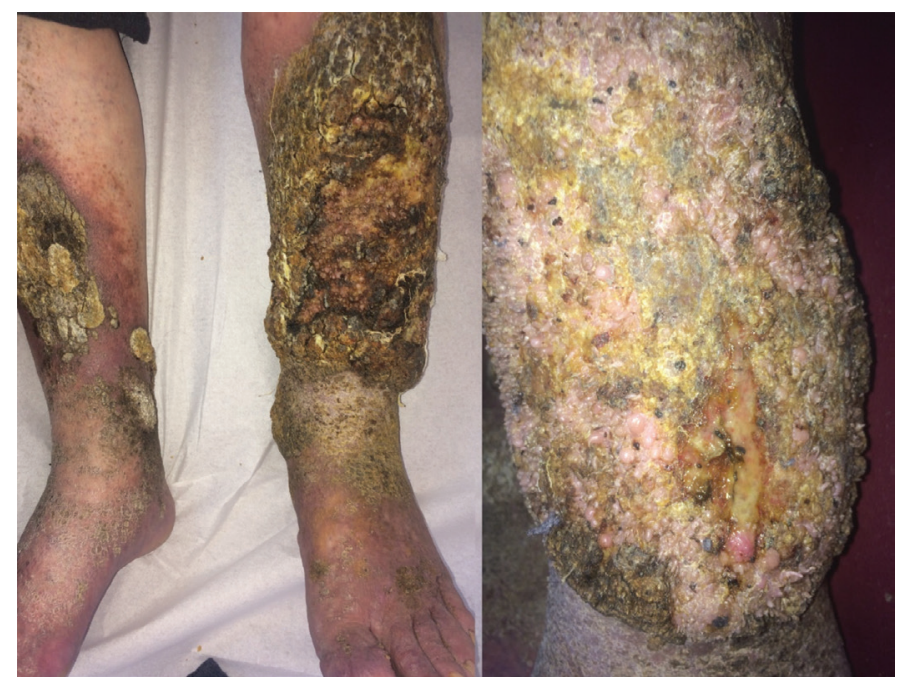

Figure 1. Bilateral lower limbs covered with yellow-brown, thick hyperkeratosis and cobblestone-like appearance under the peeled crusts, in particular, marked on the left side and diameter difference between the legs around proliferating vascular structures in the dermis. There was no dermal invasion and atypical mitosis. Periodic acid-Schiff and Gomori methenamine silver staining showed no fungal agent (Figure 3).

Although deep vein thrombosis and arterial pathology were not detected in the arterial and venous doppler ultrasonography, all of the deep venous structures, particularly on the left, had venous insufficiency findings and tortuous varicose veins were observed.

We diagnosed the patient with ENV based on clinical, histopathological manifestations. Complaints involved in ENV are flared up during periods when the patient had long-term constipation. We speculated that the primary cause of venous insufficiency may be long lasting episodes of decreasing venous return due to the frequent recurrent abdominal distension. Indeed, abdominal computed tomography (CT) showed that the sigmoid colon was $25 \times 160 \mathrm{~mm}$ and all colon segments were substantially dilated. Expanded column segments compressed the stomach, bladder and bilateral iliac veins (Figure 4).

A thorough interview revealed that the patient had been socially inactive for a long time due to his skin lesion and frequent stomachache. He had not shown his legs to even the closest relatives and refused to go to the hospital. The patient was diagnosed with Hirschsprung's disease at 20 years of age and had been treated 31 years ago. But thereafter his constipation problem has not improved because of possible secondary stricture after the operation or incomplete surgical margin. Still, he had sought no medical advice hitherto. We could observe that a severe ileus clinic developed in the patient who could defecate once every 2 weeks and had difficulty in gas extraction; his abdominal distention progressed over time and he had severe abdominal pain attacks during admission to our clinic.

The patient whose complaints regressed by antibiotherapy, except for ileus was referred to general surgery after abdominal CT since he had no defecation for more than 2 weeks, vomiting, intermittent fever and colic abdominal pains. The patient who improved by a conservative approach in the department of general surgery refused a surgical intervention to solve his constipation. So, general constipation recommendations, enema and laxative treatments were arranged and he was discharged. Informed consent was obtained.

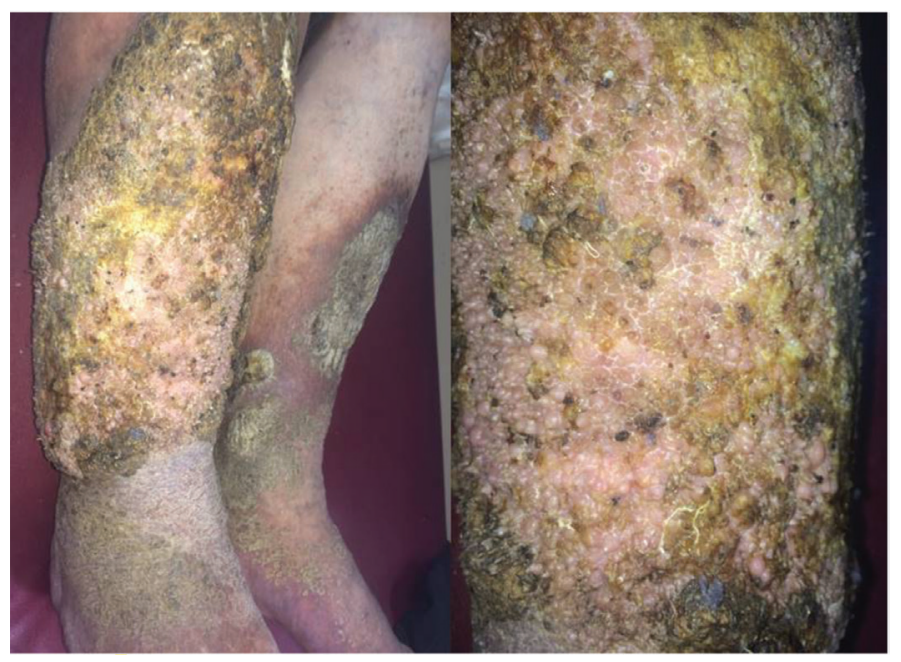

Figure 2. $7^{\text {th }}$ day of treatment (crusts continue to be removed) 


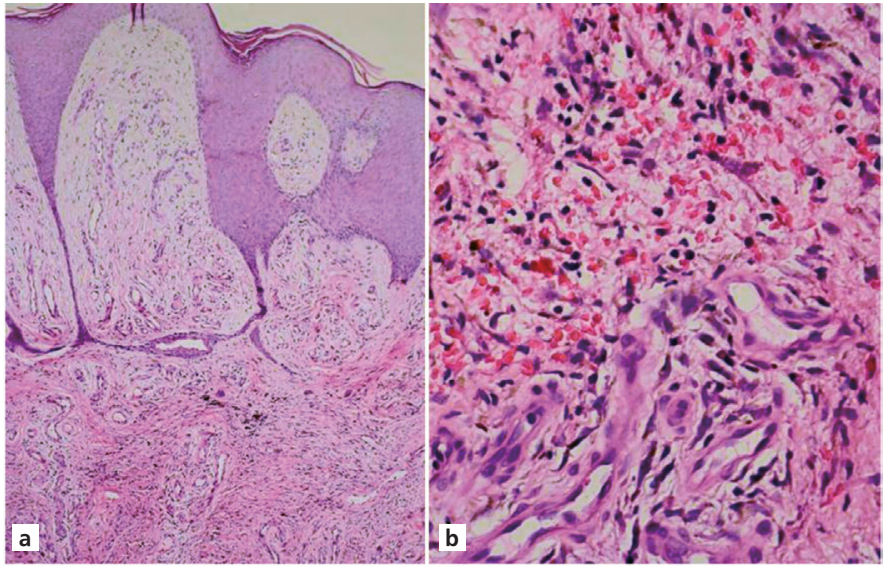

Figure 3. a) Mild hyperkeratosis in the epidermis and irregular elongation of the retes were observed. There was no dermal invasion and atypical mitosis (hematoxylin and eosin, x40). b) Extravascular erythrocytes and hemosiderin loaded macrophages, fibromyxoid stroma around proliferating vascular structures in the dermis (hematoxylin and eosin, $x 400$ )

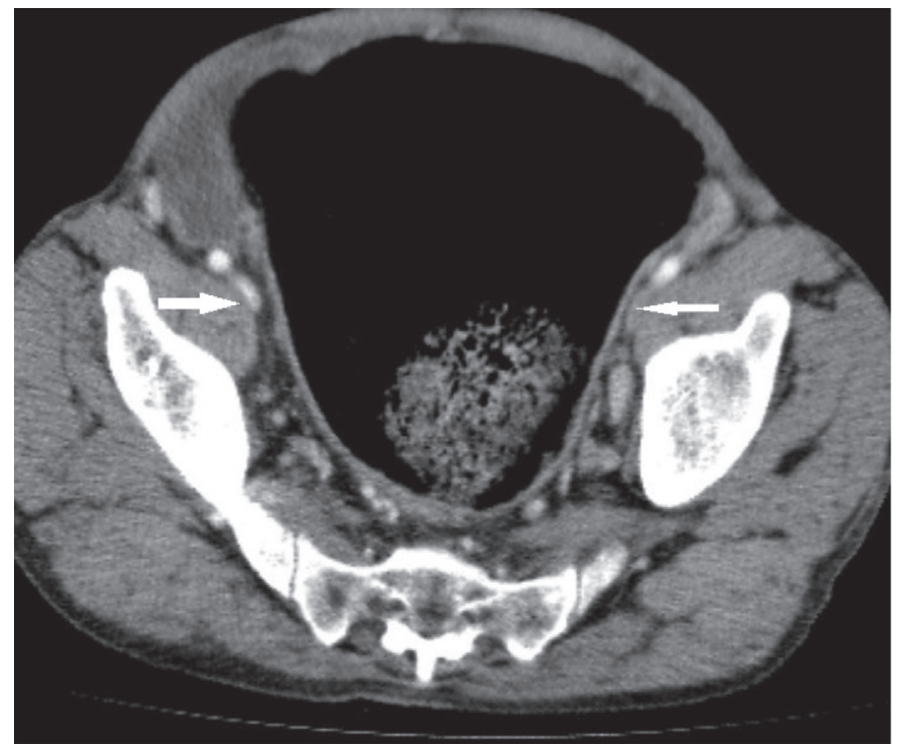

Figure 4. Axial contrast enhanced computed tomography image, dilated sigmoid colon and compressed iliac veins (arrows) can be seen

\section{Discussion}

ENV is characterized by papules, verrucous lesions which deform the affected area with time. Although the etiopathogenesis of ENV remains unclear, the most important risk factor are morbid obesity and soft-tissue infection and chronic venous insufficiency'. Whatever the etiology of elephantiasis is, the skin lesions are formed by a common pathogenesis. There is a vicious cycle in which the secondary bacterial lymphangitis and the impairment of the skin barrier feed each other. According to his suggestion, recurrent secondary infections due to disturbed lymphatic drainage will cause the process to a vicious cycle as in the present case. The affected tissue thickens by lymphatic pooling, infections, immune response followed by fibroblast proliferation and collagen accumulation ${ }^{2}$. The presence of recurrent infections in $86 \%$ of cases in a case series involving $21 \mathrm{ENV}$ cases has been reported by Dean et $\mathrm{al}^{1}$. causes such as surgery, radiotherapy, trauma, malignancy, portal hypertension, Graves' disease, hypothyroid, heart failure, pulmonary hypertension, spina bifida can give rise to ENV ${ }^{1,3,4}$. Management of ENV is challenging. Although treatment of the underlying cause is required, this is usually not possible. Antibiotics are generally used for recurrent attacks of cellulitis and compression bandages and leg elevations are recommended to reduce lymphedema. In addition, recently, patients who benefited significantly from ablative laser and acitretin for verrucous lesions were reported at the case level5,6.

There is an extremely robust association between obesity and ENV, such that Dean et al. ${ }^{1}$ reported that obesity was present in all 21 cases and even $91 \%$ were morbidly obese $\left(\mathrm{BMI} \geq 40 \mathrm{~kg} / \mathrm{m}^{2}\right)^{1}$. ENV cases have also been reported on the abdomen, which develops due to obesity ${ }^{7,8}$ Our case had severe ENV, even though he was lean (BMI: $16.6 \mathrm{~kg} /$ $\mathrm{m}^{2}$ ). However, as described above, there was chronic constipation that resulted in long-standing abdominal distension episodes that increased the intra-abdominal pressure as in obesity. Factors such as decreased diaphragm movement, interstitial lymphatic changes, increased intraabdominal pressure, fat tissue increase without proportional lymphatic proliferation may have effects in the development of obesity-associated stasis dermatitis'. From this perspective, prolonged abdominal distention due to constipation may similarly contribute to pathogenesis by increased intra-abdominal pressure and restriction of diaphragm movements. As in our case, compression to veins with a mass-like effect of expanded bowel loops is much more important. The lesions on the left side of our patient were significantly larger than on the right side. Because the left iliac vein is the vicinity of the sigmoid colon and the most affected segment is the sigmoid colon on account of distal ileus levels involved with Hirschsprung operation. Hence, we consider that the more severe ENV at the left leg may be closely related to the anatomic level of ileus and also recurrent cellulitis attacks have played a major part in the progression of the disease.

Interestingly, psychiatric conditions characterized by social withdrawal such as social anxiety disorder, depression are risk factors for ENV because of propensity to venous stasis by prolonging immobilized duration and contributing to constipation ${ }^{9,10}$. We think that it is the invisible part of the iceberg that our patient has also a social withdrawal, which is another factor contributing to the progression of the disease. ENV is a rare entity which can result from chronic constipation. The presence of the other risk factors can make the picture even worse. Here, we presented a patient with extended-constipation due to Hirschsprung's disease. Constipation resulting in expanded sigmoid colon can produce venous insufficiency and even ENV development. In addition, we underscored that the concurrent social isolation in our patient was another possible risk factor of ENV. To our knowledge, this is the first such case in the literature.

\section{Ethics}

Informed Consent: It was obtained.

Peer-review: Externally peer-reviewed.

\section{Authorship Contributions}

Surgical and Medical Practices: Ç.T., I.G.I., S.A., P.Ç., H.M.E., Concept: Ç.T., H.M.E., Design: Ç.T., I.G.I., S.A., P.Ç., H.M.E., Data Collection or 
Processing: Ç.T., I.G.I., S.A., P.Ç., Analysis or Interpretation: Ç.T., S.A., P.Ç., Literature Search: Ç.T., I.G.I., H.M.E., Writing: Ç.T., I.G.I., H.M.E.

Conflict of Interest: No conflict of interest was declared by the authors.

Financial Disclosure: The authors declared that this study has received no financial support.

\section{References}

1. Dean SM, Zirwas MJ, Horst AV: Elephantiasis nostras verrucosa: An institutional analysis of 21 cases. J Am Acad Dermatol 2011;64:1104-10.

2. Grada AA, Phillips TJ: Lymphedema: Pathophysiology and clinical manifestations. J Am Acad Dermatol 2017;77:1009-20.

3. Ukinc K, Bayraktar M, Gedik A: Hypothyroid Graves' disease complicated with elephantiasis nostras verrucosa (ENV): A case report and review of the literature. Endocrine 2009;36:6-9.

4. Manzione A, Barberi S, Scrivano J, et al: Resolution of septic shock in a patient with myelomeningocele (spina bifida) complicated with deforming elephantiasis nostras verrucosa. J Am Acad Dermatol 2015;72.
5. Low DW, Jamil A, Nor NM: Acitretin an additional treatment option for elephantiasis nostras verrucosa: a case report. Malaysian Journal of Dermatology 2017;38:79-82.

6. Robinson CG, Lee KR, Thomas VD: The successful treatment of elephantiasis nostras verrucosa with ablative carbon dioxide laser. J Cutan Med Surg 2018;22:611-3.

7. Buyuktas D, Arslan E, Celik O, Tasan E, Demirkesen C, Gündoğdu S: Elephantiasis nostras verrucosa on the abdomen of a Turkish female patient caused by morbid obesity. Dermatol Online J 2010;16:14.

8. Sarma PS, Ghorpade A: Elephantiasis nostras verrucosa on the legs and abdomen with morbid obesity in an Indian lady. Dermatol Online J 2008;14:20.

9. Simon Llanes J, Coll Vilar I, Tamarit Frances C, Castro IN: Elephantiasis nostras verrucosa in a patient with major depressive disorder. Semergen 2012;38:526-9.

10. Domingues-Castro MS, Torres AR: Hikikomori: review on a severe phenomenon of social withdrawal. Jornal Brasileiro de Psiquiatria 2018;67:264-72. 